\title{
Growth of canola hybrids resistant and sensitive to herbicides
}

\section{Crescimento de híbridos de canola resistentes e sensível a herbicidas}

\author{
Miria Rosa Durigon ${ }^{1 *}$; Joanei Cechin ${ }^{2}$; Franciele Mariani ${ }^{3}$; Gerarda Beatriz Pinto \\ da Silva ${ }^{4}$; Leandro Vargas ${ }^{5}$; Geraldo Chavarria ${ }^{6}$
}

\begin{abstract}
Highlights:
Hybrid Hyola 555TT had lower leaf dry matter at flowering then Hyola 61.

At flowering, hybrid Hyola 571CL had lower leaf area and dry matter than Hyola 61.

Hyola 555TT, Hyola 571CL, and Hyola 61 hybrids did not differ in grain yield.
\end{abstract}

\begin{abstract}
Plant growth analysis is useful for determining adequate management practices and exploring the maximum yield potential of cultivars or hybrids. Canola hybrids with resistance to herbicides have been studied and registered for Brazilian conditions, as they improve weed management in canola crops. This study evaluated the growth of canola hybrids resistant to triazine or imidazolinone herbicides compared to a sensitive hybrid. The experiment was conducted using a completely randomized design, with four replications, in a bifactorial scheme using three hybrids and six sampling times. The canola hybrids used were Hyola 571CL (resistant to imidazolinones), Hyola 555TT (resistant to triazines), and Hyola 61 (sensitive to both herbicides). Height, leaf area, and dry matter of roots, leaves, stems, and shoots of the plants were evaluated at 14, 28, 42, 56, 70, and 119 days after emergence (DAE). The physiological indices absolute growth rate, leaf area ratio, specific leaf area, and net assimilation rate were calculated, and yield indices evaluated. Compared to Hyola 61, the Hyola 555TT hybrid showed lower values of leaf dry matter at $70 \mathrm{DAE}$, absolute growth rate up to $56 \mathrm{DAE}$, and net assimilation rate at 14 and 28 DAE, and a higher leaf area ratio at 56 DAE, whereas the hybrid Hyola 571CL presented lower leaf area and lower leaf dry matter at 70 DAE. At flowering, compared to Hyola 61, the hybrid Hyola 571CL presents lower leaf area, and the hybrids Hyola 555TT and Hyola 571CL have lower leaf dry matter accumulation. Differences in the growth of canola hybrids Hyola 555TT, Hyola 571CL and Hyola 61 do not cause differences in their grain yield.
\end{abstract}

Key words: Brassica napus L. Dry matter. Growth rate. Leaf area. Yield indices.

\footnotetext{
1 Dra ., Curso de Doutorado do Programa de Pós-Graduação em Agronomia, Universidade de Passo Fundo, UPF, Faculdade de Agronomia e Medicina Veterinária, Passo Fundo, RS, Brasil. E-mail: midurigon@hotmail.com

2 Prof. Dr., Universidade Estadual de Ponta Grossa, UEPG, Departamento de Fitotecnia e Fitossanidade, Ponta Grossa, PR, Brasil. E-mail: joaneicechin@yahoo.com.br

3 Profa. Dra ${ }^{\mathrm{a}}$, Instituto Federal de Educação, Ciência e Tecnologia de Santa Catarina, IFSC, Departamento de Agronomia, São Miguel do Oeste, SC, Brasil. E-mail: marianifranciele@gmail.com

4 Dra., Trainee, GDM Seeds, Porto Nacional, TO, Brasil. E-mail: gpsilva@gdmseeds.com

5 Dr., Pesquisador, Empresa Brasileira de Pesquisa Agropecuária, EMBRAPA, Centro Nacional de Pesquisa de Trigo, Laboratório de Plantas Daninhas, Passo Fundo, RS, Brasil. E-mail: leandro.vargas@embrapa.br

6 Prof. Dr., UPF, Programa de Pós-Graduação em Agronomia, Faculdade de Agronomia e Medicina Veterinária, Passo Fundo, RS, Brasil. E-mail: geraldochavarria@upf.br

* Author for correspondence
} 


\section{Resumo}

A análise de crescimento de plantas é útil para determinar práticas de manejo adequadas e explorar o máximo potencial de rendimento de cultivares ou híbridos. Híbridos de canola com resistência a herbicidas têm sido estudados e registrados para as condições brasileiras, visto que melhoram o manejo de plantas daninhas nas lavouras de canola. Este estudo avaliou o crescimento de híbridos de canola resistentes a herbicidas triazinas ou imidazolinonas comparado a um híbrido sensível. O experimento foi conduzido usando o delineamento inteiramente casualizado, com quatro repetições, em um esquema bifatorial usando três híbridos e seis épocas de amostragem. Os híbridos de canola utilizados foram Hyola 571CL (resistente a imidazolinonas), Hyola 555TT (resistente a triazinas) e Hyola 61 (sensível a ambos os herbicidas). A estatura, área foliar e massa seca de raízes, folhas, caules e partes aéreas das plantas foram avaliadas aos 14, 28, 42, 56, 70 e 119 dias após a emergência (DAE). Os índices fisiológicos taxa de crescimento absoluto, razão de área foliar, área foliar específica e taxa de assimilação líquida foram calculados e os índices de rendimento avaliados. Comparativamente ao Hyola 61, o híbrido Hyola 555TT apresentou menores valores de massa seca de folhas aos $70 \mathrm{DAE}$, taxa de crescimento absoluto até os 56 DAE e taxa de assimilação líquida aos 14 e 28 DAE e uma maior razão de área foliar aos 56 DAE, enquanto que o híbrido Hyola 571CL apresentou menor área foliar e menor massa seca de folhas aos 70 DAE. No florescimento, comparativamente ao Hyola 61, o híbrido Hyola 571CL apresenta menor área foliar e os híbridos Hyola 555TT e Hyola 571CL possuem menor acúmulo de massa seca de folhas. Diferenças no crescimento dos híbridos de canola Hyola 555TT, Hyola 571CL e Hyola 61 não ocasionam mudanças no seu rendimento de grãos.

Palavras-chave: Brassica napus L. Massa seca. Taxa de crescimento. Área foliar. Índices de rendimento.

\section{Introduction}

Herbicides are essential for weed management in many agricultural areas because of their ability to maintain crop yield potential. Since 1996, the introduction of crops resistant to herbicides has contributed significantly to reduce production costs because they enable high weed control efficiency, which increases yield and optimizes conservation practices (Duke, 2015).

Canola (Brassica napus L. var. oleifera) is an economical and important crop for rotation in the cold growing season, and the use of herbicideresistant hybrids can contribute to the management of weeds that are difficult to control. In Brazil, canola production covers approximately 48,000 hectares and herbicide-resistant hybrids from the imidazolinone chemical group (Canola Clearfield ${ }^{\circledR}$, $\mathrm{CL}$ ) or conventional hybrids are grown (Companhia Nacional de Abastecimento [CONAB], 2018; Ministério da Agricultura, Pecuária e Abastecimento [MAPA], 2018). Herbicide resistance in Clearfield canola occurs through a simple substitution of the amino acid serine by asparagine at position 653 in the acetolactate synthase (ALS) gene, accomplished by induced mutation (Tan, Evans, Dahmer, Singh, \& Shaner, 2005). In susceptible plants, imidazolinone herbicides cause inhibition of the ALS enzyme, blocking synthesis of the branched-chain amino acids: valine, leucine, and isoleucine (Vargas \& Roman, 2006).

Weed management options for canola cropping, although still under evaluation, include the use of triazine-resistant hybrids (TT). This technology, in canola, presents as a mechanism of resistance a mutation at position 264 in the $p s b A$ gene of the chloroplast D1 protein, with substitution of serine by glycine. These hybrids were obtained by recurrent backcrossing between a resistant weed, that evolved due to field selection by atrazine herbicides, and a canola crop (Tranel \& Horvath, 2009). In susceptible plants, triazine herbicides inhibit the electron flow from photosystem II (PSII) in the thylakoid membrane and trigger the accumulation of free radicals, causing lipid peroxidation and cellular leakage (Friesen \& Powles, 2007). 
Plant adaptation to a new environment often has negative pleiotropic effects on suitability in the original environment, the so-called fitness cost (Purrington, 2000; Vila-Aiub, Neve, \& Powles, 2009). In crops, many changes that result in resistance to herbicides may lead to a fitness cost, usually characterized by reduced growth and grain yield potential compared to hybrids without the herbicide-resistance gene (Vila-Aiub, Gundel, \& Preston, 2015). However, the survival of hybrids exposed to herbicides can be considered an adaptive advantage when compared to susceptible plants, although it depends on the mechanism of resistance involved (Yu, Han, Vila-Aiub, \& Powles, 2010; Délye, Jasieniuk, \& Le Corre, 2013). Mutations in the ALS gene usually do not cause fitness costs in herbicide-resistant plants of the imidazolinone chemical group, which is considered an advantage for cultivated plants (Tranel \& Wright, 2002; Tranel \& Horvath, 2009). Regarding $p s b A$ gene mutations in chloroplast proteins, as found in canola TT, a yield reduction higher than $20 \%$ due to the reorganization of its structure, and changes in electron transfer have been reported (Darmency, 2013). However, considering all the difficulties in the management and production of canola crops, the use of herbicide-resistant canola hybrids is essential for dicotyledonous weed control due to the absence of selective molecules for the crop in post-emergence (Vargas, Tomm, Ruchel, \& Kaspary, 2011), a scenario that could compensate the existence of fitness costs and protect the yield potential. Furthermore, crop rotation is a premise of the no-tillage system and an important practice to avoid the evolution of weed resistance, mainly when only CL hybrids are used. In this case, the selection of species from different botanical families and an adequate sequence of crops are fundamental for successful cropping systems (Wei, Liping, Zhijun, Guangwei, \& Ruirui, 2010).

Changes in resource allocation and growth rate can affect the capacity of crops and weeds to compete for limited environmental resources (Vila-Aiub et al., 2015). In weeds, adaptability studies to evaluate growth parameters and predict their invasive potential as a function of the use of environmental resources are quite common (Radosevich, Holt, \& Ghersa, 2007; Londo, Bollman, Sagers, Lee, \& Watrud, 2011). Adaptability evaluation of cultivated plants is less common; however, an understanding of the fitness costs based on vegetative growth and grain yield characteristics in herbicide-resistant genotypes is a crucial tool for mitigating ecological impacts and managing weeds in cultivated areas (Darmency, 2013).

Therefore, it is hypothesized that herbicideresistant canola hybrids of the triazine chemical group have lower growth compared to imidazolinoneresistant, and sensitive canola hybrids. This study aimed to evaluate the growth of canola hybrids with resistance to triazine or imidazolinone herbicides compared to a herbicide-sensitive hybrid.

\section{Material and Methods}

The experiment was carried out in a greenhouse, using a completely randomized experimental design with four replications, and a two-factorial scheme composed of three canola hybrids and six sampling times. The canola hybrids used were Hyola 571CL (resistant to herbicides of the imidazolinone group), Hyola 555TT (resistant to triazines), and Hyola 61 (herbicide-sensitive). Besides their herbicide resistance/susceptibility traits, these hybrids have a different genetic basis. All canola plants were grown without herbicide application during the experiment.

Seeds of each hybrid were germinated in trays filled with humic dystrophic Red Latosol (clay: $62 \%, \mathrm{pH}: 6.2$, organic matter: $2 \%, \mathrm{CEC}_{\mathrm{pH} 7.0}: 13.4$ $\mathrm{cmol}_{\mathrm{c}} \mathrm{dm}^{-3}$, base saturation: $79.4 \%$, phosphorus: $15.6 \mathrm{mg} \mathrm{dm}^{-3}$, and potassium: $166 \mathrm{mg} \mathrm{dm}^{-3}$ ), and peat substrate (Plantas Garden Plus Turfa Fértil). At two days after emergence, individual canola seedlings were transplanted into pots (experimental units), each with a 9-L volumetric capacity and 24 
$\mathrm{cm}$ surface diameter containing soil and substrate in a 2:1 ratio. The seedling transplant process was used to standardize the plants of each hybrid, thus reducing the experimental error.

Growth evaluations were performed at 14, 28, 42, 56, 70 (flowering), and 119 (physiological maturity) days after emergence (DAE) through determination of the following parameters: plant height $(\mathrm{PH} ; \mathrm{cm})$, leaf area $\left(\mathrm{LA} ; \mathrm{cm}^{2}\right)$, and stem (SDM; g), leaf (LDM; g), root (RDM; g), and shoot total dry matter (STDM; g) at each time interval. A millimeter ruler was used to measure $\mathrm{PH}$ from the soil level to the inflection of the last leaf. For dry matter determination, the plants were separated into stems, leaves, and roots, placed in paper bags and oven-dried at $60{ }^{\circ} \mathrm{C}$ for 72 hours, then weighed on an analytical balance. Leaf area was recorded up to 70 DAE using a leaf area meter (LICOR LI-3100C, LI-COR Biosciences, Lincoln, Nebraska, U.S.A), and measuring only the photosynthetically active plant leaves (green leaves).

The absolute growth rate (AGR), leaf area ratio (LAR), specific leaf area (SLA), and net assimilation rate (NAR) were calculated indirectly, based on the values obtained for LA, STDM, and LDM for the time interval between two samplings (Benincasa, 2003), using the following equations: $\mathrm{AGR}=\left(\mathrm{STDM}_{2}-\mathrm{STDM}_{1}\right) /\left(\mathrm{T}_{2}-\mathrm{T}_{1}\right)$ in $\mathrm{g} \mathrm{day}^{-1}$; $\mathrm{LAR}=\mathrm{LA} / \mathrm{STDM}$ in $\mathrm{cm}^{2} \mathrm{~g}^{-1}$; SLA $=\mathrm{LA} / \mathrm{LDM}$ in $\mathrm{cm}^{2} \mathrm{~g}^{-1} ;$ and NAR $=\left[\left(\mathrm{STDM}_{2}-\mathrm{STDM}_{1}\right) \times\left(\operatorname{lnLA}_{2}\right.\right.$ $\left.\left.\left.-\ln \mathrm{LA}_{1}\right) /\left(\mathrm{LA}_{2}-\mathrm{LA}_{1}\right) \times\left(\mathrm{T}_{2}-\mathrm{T}_{1}\right)\right] / 0.01\right)$ in $\mathrm{g}$ $\mathrm{dm}^{-2}$ day $^{-1}$. The number of seeds silique ${ }^{-1}$, siliques plant $^{-1}$, seeds plant ${ }^{-1}$, and seed weight plant $^{-1}(\mathrm{~g})$ were determined at the end of the growth cycle of each hybrid.

The data obtained were subjected to analysis of variance $(p \leq 0.05)$. Regression analysis was performed for the factor sampling times of each hybrid when the interaction was significant. However, when there was no significant interaction, regression analysis was carried out for the mean of the hybrids. Figures presenting the regressions and minimum significant differences were created using SigmaPlot 11.0 (Systat Software Inc. [SYSTAT], $2008)$. Analysis of variance $(p \leq 0.05)$ and a means comparison test (Tukey's test, $p \leq 0.05$ ) were used for analysis of the variables: number of seeds silique $^{-1}$, siliques plant ${ }^{-1}$, seeds plant ${ }^{-1}$, and seed weight plant $^{-1}$.

\section{Results and Discussion}

A significant interaction between canola hybrids and sampling times was found for plant height $(\mathrm{PH})$, stem dry matter (SDM), root dry matter (RDM), leaf area (LA), leaf dry matter (LDM), absolute growth rate (AGR), leaf area ratio (LAR), and net assimilation rate (NAR) (Figures 1, 2, and 3 ), and simple effects were found for the variables shoot total dry matter (STDM) and specific leaf area (SLA) (Figures 1 and 3).

A sigmoidal model $\left[y=a /\left(1+e^{(-(x-x 0) / b)}\right)\right]$ was adjusted for PH, SDM, RDM, and STDM of canola hybrids with a higher accumulation from 42 to 70 DAE. It should be emphasized that the tested hybrids had an early and similar cycle, ranging from 140 to 155 days to reach physiological maturity (Tomm, Ferreira, \& Vieira, 2014). The critical period to prevent interference in canola is from 25 to 60 DAE, depending on the hybrid, soil and climatic conditions, plant spacing, management, cultural traits, and weed community found in a particular cultivated field (Brandler, 2019). Thus, rapid plant development, especially at early stages, is an essential characteristic for competition because it enables greater capacity to capture environmental resources and occupy the available space (Agostinetto, Fontana, Vargas, Markus, \& Oliveira, 2013).

The PH was similar for all hybrids from 28 to 56 DAE, with significant differences found at 14, 70 and 119 DAE (Figure 1A). The PH for the Hyola 571CL and Hyola 555TT hybrids did not differ statistically at 119 DAE, but was $16 \%$ higher when compared to hybrid Hyola 61 (Figure 1A). 


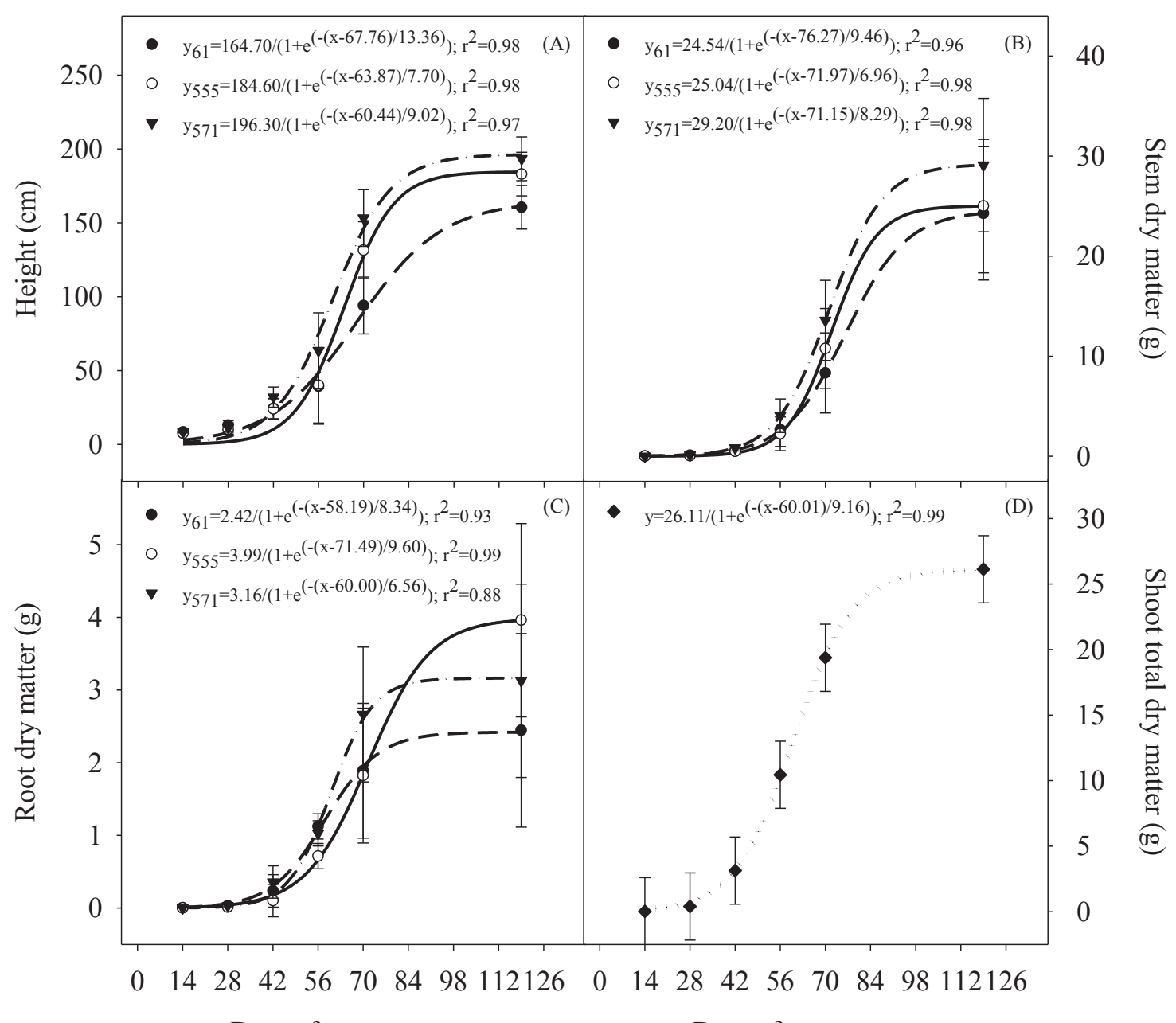

Days after emergence

Days after emergence

--- Hyola $61 \quad$ Hyola 555TT $\quad-\cdot-\cdot$ Hyola $571 \mathrm{CL} \quad \cdots \cdot$ Mean of hybrids

Figure 1. Height (A), stem dry matter (B), root dry matter (C), and shoot total dry matter (D) of the canola hybrids Hyola 61 (61), Hyola 555TT (555), and Hyola 571CL (571) from 14 to 119 days after emergence, with curves adjusted to the sigmoidal model. Bars represent the minimum significant difference of the measurements.

For SDM, differences were observed from 42 to 70 DAE where the Hyola 571CL hybrid showed higher values (Figure 1B). However, the hybrids did not show significant differences in SDM accumulation at 119 DAE. The Hyola 555TT hybrid showed the lowest RDM from 28 to 56 DAE; however, by 119 DAE it had the highest RDM values, which were $66 \%$ greater when compared to the Hyola 61 hybrid (Figure 1C). A simple effect of evaluation times was observed for STDM, with greater daily accumulation between 42 and 84 DAE and maximum STDM values of approximately $27 \mathrm{~g}$ plant $^{-1}$ at 119 DAE (Figure 1D).

A non-linear sigmoidal model was adjusted for LA and LDM. The Hyola 555TT hybrid showed the lowest values at 28 and 42 DAE for LA, and from 14 to 42 DAE for LDM (Figure 2). However, the Hyola 61 hybrid presented values for LA $(\approx 2878$ $\left.\mathrm{cm}^{2}\right)$ and $\mathrm{LDM}(\approx 11 \mathrm{~g})$ up to $30 \%$ higher at 70 DAE when compared to hybrids resistant to ALS and photosystem II (PSII) inhibiting herbicides (Figure 2). 


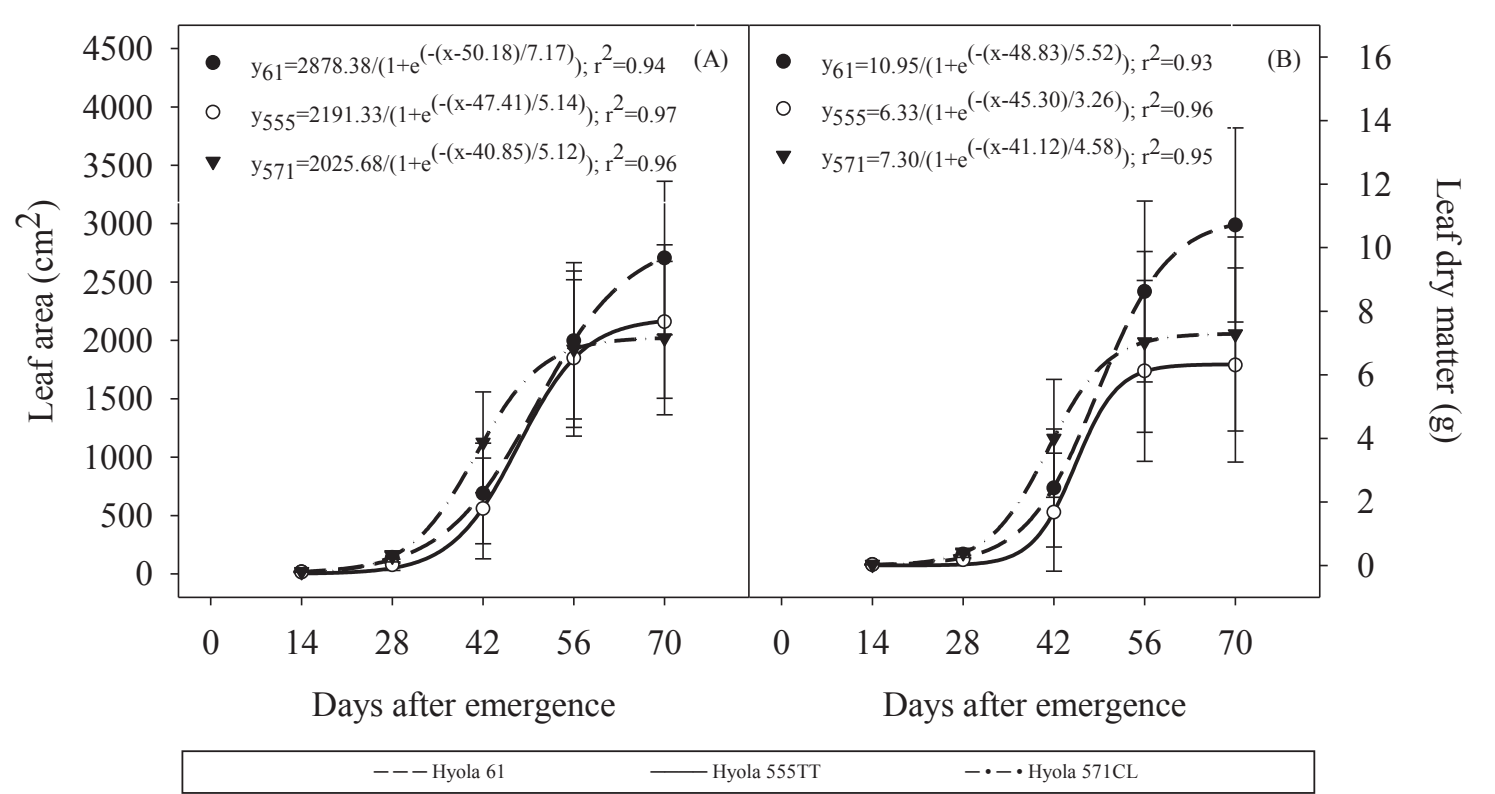

Figure 2. Leaf area (A) and leaf dry matter (B) of the canola hybrids Hyola 61 (61), Hyola 555TT (555), and Hyola 571CL (571) from 14 to 70 days after emergence, with curves adjusted to the sigmoidal model. Bars represent the minimum significant difference of the measurements.

Plant dry matter production at different development stages is directly related to photosynthesis and respiration processes (Cruz, 2013). During photosynthesis, plants use solar energy to oxidize water, releasing oxygen and electrons to reduce carbon dioxide and form carbon compounds and sugars (Taiz \& Zeiger, 2017). Energy and substrates are generated during respiration for biochemical processes involving maintenance of existing structures (maintenance respiration), as well as for the formation of new structures and cell components (growth respiration) (Majerowicz, 2013). Despite that the STDM did not differ between hybrids, the Hyola 555TT hybrid showed a later increment in LDM, SDM, RDM, and LA, indicating slower growth compared to the other hybrids.

Mutation in the $p s b A$ gene for triazine resistance in cultivated crops results in a conformational change of the D1 protein (present in photosystem II) which is responsible for binding $\mathrm{B}$ quinone for electron transport (Friesen \& Powles, 2007). Because of this conformational change, and the complete reorganization of chloroplast structure during development, some effects on fitness costs in triazine-resistant plants have been documented, including a reduction in electron transfer, firstly in PSII, which may be less evident under low temperature and luminosity (Darmency, 2013).

For ALS inhibiting herbicides, some amino acid residues are important in herbicide binding and maintenance of catalytic activity (e.g., Phe206, Arg-377, and Trp-574), and changes in these residues may result in fitness costs associated with growth and seed production (Tardif, Rajcan, \& Costea, 2006; Yu \& Powles, 2014). For Clearfield crops, although mutations in Ser-653 may cause a reduction in leaf size, they do not lead to a significant effect on fitness costs since imidazolinones are noncompetitive inhibitors of the ALS enzyme, and do not significantly affect enzyme activity (McCourt, Pang, King-Scott, Guddat, \& Duggleby, 2006). Imidazolinone herbicides do not bind directly to the active site of the ALS enzyme, but in close proximity to it, blocking substrate access and thereafter inhibiting the enzyme activity in herbicide-sensitive 
crops, so that the herbicide resistance not incur loss or major reduction in ALS activity (Yu \& Powles, 2014).

The absolute growth rate (AGR), leaf area ratio (LAR), and net assimilation rate (NAR) findings showed interactions between hybrids and evaluation times, with adjustment to the cubic polynomial $[\mathrm{y}=$ $\left.a x^{3}+b x^{2}+c x+d\right]$, exponential $\left[y=a \times e^{b x}\right]$, and quadratic $\left[y=a x^{2}+b x+c\right]$ models, respectively (Figure 3A, B, and C). There was no interaction for specific leaf area (SLA), and the means of hybrids for each evaluated time were adjusted to a quadratic model (Figure 3D). The results for AGR and NAR showed a similar pattern between hybrids for all times, with a lower increase for the hybrid Hyola 555TT up to $56 \mathrm{DAE}$ (Figure 3A and C). The AGR expresses plant growth rate over time, while the NAR reflects energy conversion efficiency for the dry matter production (A. C. Silva, Ferreira, Silva, \& Ferreira, 2005; Oliveira, Paiva, Alvarenga, \& Nogueira, 2006). Plants with a higher dry matter accumulation over a shorter period of time have a higher competitive ability when in competition for available resources with other plants (Carvalho et al., 2005; Radosevich et al., 2007). The lower AGR and NAR values for the hybrid Hyola 555TT suggest it may be less able to compete with weeds than the other hybrids (Figure 3A and C). Based on the model, the maximum NAR values were 0.055 , 0.051 , and $0.058 \mathrm{~g} \mathrm{dm}^{-2} \mathrm{day}^{-1}$ at 37, 42, and $36 \mathrm{DAE}$ in the hybrids Hyola 61, Hyola 555TT, and Hyola 571CL, respectively (Figure 3C).

The LAR decreased in a similar way for all three hybrids from 14 to 70 DAE (Figure 3B). The LAR represents the leaf area used by a plant to produce one gram of shoot dry matter, and is thus appropriate for evaluating the effects of genotype, environment, and management on plants (Oliveira et al., 2006). In the present study, LAR values were similar between hybrids for the evaluated period, ranging from 524.95 to $109.88 \mathrm{~cm}^{2} \mathrm{~g}^{-1}$ at 14 and 70 DAE, respectively (Figure 3B). Similar LAR values were observed when evaluating the fitness cost in radish (Raphanus sativus L.) biotypes resistant and susceptible to ALS inhibiting herbicides, with values ranging from 400 to $100 \mathrm{~cm}^{2} \mathrm{~g}^{-1}$ at 14 and 80 DAE, respectively (Cechin et al., 2017). However, the results for the hybrid Hyola 555TT suggest a need of a greater leaf area to produce STDM, which may be related to its lower photosynthetic efficiency when compared to the other hybrids, as reflected by the NAR values (Figure 3C). Accessions of Brachypodium hybridum resistant to PSII inhibiting herbicides were recently reported as less competitive when compared to susceptible plants competing with wheat, which was related to a lower efficiency of the photosynthetic apparatus due to structural alteration of the D1 protein (Frenkel, Matzrafi, Rubin, \& Peleg, 2017).

No significant interaction was observed between the evaluated factors for SLA which showed a reduction of $19.9 \mathrm{~cm}^{2} \mathrm{~g}^{-1}$ from 14 to $55 \mathrm{DAE}$, when the minimum value of $277 \mathrm{~cm}^{2} \mathrm{~g}^{-1}$ was observed for the mean of the evaluated hybrids (Figure 3D). The SLA is a measure of average leaf expansion, in area, per unit leaf dry matter, which indirectly defines the density or thickness of leaves (L. C. Silva, Belterão, \& Amorim, 2000). The reduction in SLA up to 55 DAE indicates an accumulation of photoassimilates in leaves of the evaluated hybrids, increasing their density and thickness. The SLA values increased from 55 to $70 \mathrm{DAE}$, suggesting that there was translocation of photoassimilates to other plant organs (Taiz \& Zeiger, 2017). This result correlates with the developmental stage of the plants since flowering started from 55 DAE, and excess sugars produced by the leaves are likely to have been translocated to the flowers, reflecting changes in the source-drain relationships of the plants. 


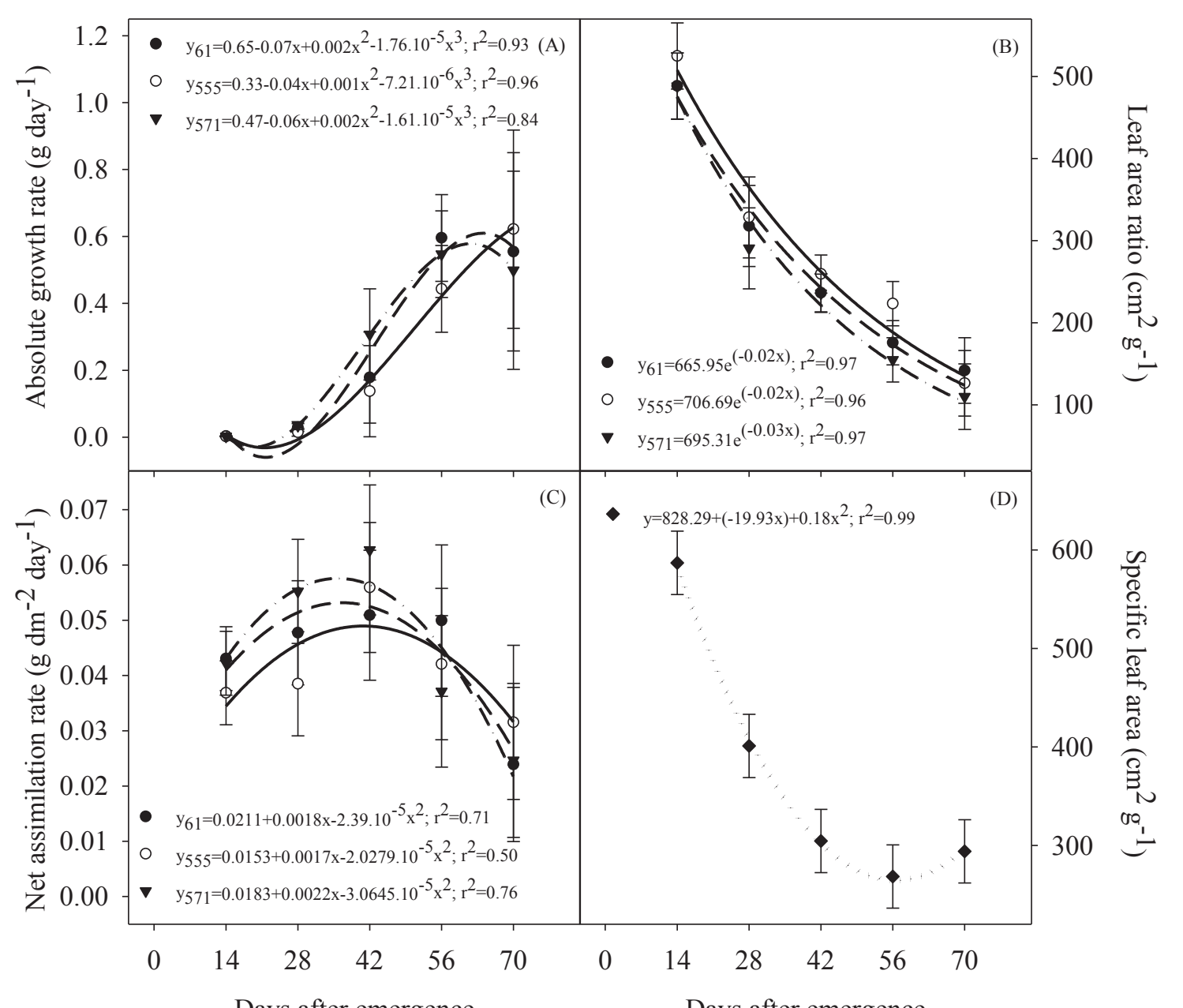

Days after emergence

Days after emergence

\begin{tabular}{llll}
\hline-- Hyola 61 & - Hyola $555 T$ TT & $-\cdot-\cdot$ Hyola $571 \mathrm{CL}$ & $\cdots \cdot \cdot$ Mean of hybrids \\
\hline
\end{tabular}

Figure 3. Absolute growth rate (A), leaf area ratio (B), net assimilation rate (C), and specific leaf area (D) of the canola hybrids Hyola 61 (61), Hyola 555TT (555), and Hyola 571CL (571) from 14 to 70 days after emergence, with curves adjusted to the cubic polynomial (A), exponential (B), and quadratic (C and D) models. Bars represent the minimum significant difference of the measurements.

Considering the yield indices at physiological maturity for the hybrids Hyola 61, Hyola 555TT, and Hyola 571CL, no significant effect was observed for the number of siliques plant ${ }^{-1}$, number of seeds silique $^{-1}$, and seed weight plant $^{-1}$, but a significant difference was observed for number of seeds plant $^{-1}$ (Table 1). The number of seeds plant ${ }^{-1}$ was highest for the hybrid Hyola 61, which differed only from Hyola 571CL. The seed production per plant was 46.8 and $19.7 \%$ higher for Hyola 61 in comparison to Hyola 571CL and Hyola 555TT, respectively.
The differences observed in plant growth of the hybrid Hyola 555TT compared to the hybrids Hyola 571CL and Hyola 61, such as lower PH at 14 DAE, lower RDM at 28 and 56 DAE, lower LA, LDM and AGR at 28 DAE and a higher LAR at 56 DAE, indicated that the Hyola 555TT hybrid had slower growth until 56 DAE. In contrast, AGR, LAR, and NAR did not differ between hybrids at 70 DAE. During this time period, Hyola 61 presented higher LA (but not different from Hyola 555TT), and higher LDM. At 119 DAE, Hyola 555TT had 
higher RDM (but not different from Hyola 571CL), and both hybrids had greater PH. The differences in growth parameters found in canola hybrids during development could demonstrate differential nutrient allocation. Such results correlate with the observed grain yield since the hybrids showed no differences in seed weight plant ${ }^{-1}$. Although the number of seeds plant ${ }^{-1}$ is a yield component, it cannot be used in isolation to predict grain yield differences of genotypes since the thousand-grain weight can vary between them and influence the final seed weight. This was observed in the present study, where the thousand-grain weight balanced the differences found between hybrids for the number of seeds plant $^{-1}$, with no difference observed for seed weight plant $^{-1}$. Yield components have presented a direct and positive correlation with canola grain yield, being strongly influenced by environment and agronomic management practices (Krüger et al., 2011).

Table 1

Yield indices of the canola hybrids Hyola 61, Hyola 555TT, and Hyola 571CL at 119 days after emergence

\begin{tabular}{|c|c|c|c|c|c|}
\hline \multirow{2}{*}{ Variable } & \multicolumn{4}{|c|}{ Hybrid } & \multirow{2}{*}{$\mathrm{CV}^{1}(\%)$} \\
\hline & Hyola 61 & Hyola 5 & $5 \mathrm{TT}$ & Hyola 571CL & \\
\hline Seeds silique $^{-1}$ & $7.10 \mathrm{a}^{*}$ & 5.96 & $\mathbf{a}$ & $5.78 \quad \mathbf{a}$ & 32.4 \\
\hline Siliques plant ${ }^{-1}$ & $255.25 \mathbf{a}$ & 236.00 & $\mathbf{a}$ & 178.75 a & 20.7 \\
\hline Seeds plant ${ }^{-1}$ & $1686.25 \mathbf{a}$ & 1408.50 & $\mathbf{a b}$ & $1148.50 \quad \mathbf{b}$ & 35.6 \\
\hline Seed weight plant ${ }^{-1}(\mathrm{~g})$ & $5.14 \mathbf{a}$ & 4.66 & $\mathbf{a}$ & $4.12 \mathbf{a}$ & 35.9 \\
\hline
\end{tabular}

${ }^{1} \mathrm{CV}$ : coefficient of variation. *Means followed by the same letters in the row do not differ from each other by Tukey's test $(p \leq 0.05)$.

Initially, triazine-resistant canola was associated with a reduction in the conversion of solar energy to biomass, resulting in a reduction in grain yield and oil content when compared to triazine-sensitive cultivars (Edwards \& Hertel, 2011). In the present study, no difference was observed for the seed weight plant $^{-1}$ between the triazine-resistant hybrid (Hyola 555TT) and the sensitive hybrid (Hyola 61). This finding corroborates reports for some recently released hybrids, in which this disadvantage is lower or non-existent (Tomm et al., 2016 ${ }^{1}$ ). Although the hybrids used in the present study have a different genetic basis, knowledge about their yield is essential from a practical perspective, making it possible to recommend a hybrid for a given environment from these studies. Similarly, grain yield expressed as seed weight plant ${ }^{-1}$ in the hybrid Hyola 571CL did not differ from that in the sensitive hybrid (Table 1). Resistance in the hybrid Hyola 571CL is to herbicides of the imidazolinone group only, possibly associated with the mutation at codon 653 , from serine to asparagine, with no alteration in the functionality of the ALS enzyme in comparison to the hybrids Hyola 555TT and Hyola 61 (Durigon, Mariani, Santos, Vargas, \& Chavarria, 2018). In the same way, the mutation of Ser-653 in wheat and sunflower plants, conferring resistance to the herbicide imazamox, did not cause significant reduction in crop yield (Pozniak, Holm, \& Hucl, 2004; Massinga, Al-Khatib, St. Amand, \& Miller, 2005). Several studies on plant resistance through mutation in the ALS gene have shown no fitness cost associated with resistance, which is expected because the interaction between the herbicide and the enzyme occurs at some distance from its catalytic center (Yu \& Powles, 2014).

${ }^{1}$ Tomm, G.O. Embrapa/CNPT, Personal Communication, 2016. 
A low or no fitness cost for crops with specific gene mutations which confer resistance to herbicides is considered essential for weed control, and the use of such cultivars may be advantageous in compensating for losses caused by competition (Darmency, 2013). However, management practices should be implemented to avoid the appearance of herbicide resistant weed biotypes, including crop and hybrid rotation, weed management during the crop offseason, and planting of cover crops. In addition, adoption of other good practices is needed such as adequate liming and fertilizing, choice of areas without a history of high infestation of dicotyledonous weeds, use of certified seeds, and correct sowing with adequate spacing, population, and depth, enabling a competitive advantage for the canola crop (Durigon, Vargas, Chavarria, \& Tomm, 2016).

\section{Conclusions}

Lower absolute growth and net assimilation rates in the triazine-resistant Hyola 555TT hybrid cause lower leaf dry matter accumulation at flowering compared to the herbicide-sensitive Hyola 61 hybrid.

The imidazolinone-resistant Hyola 571CL hybrid has a lower leaf area and leaf dry matter accumulation at flowering than the herbicidesensitive Hyola 61 hybrid.

Vegetative growth differences in Hyola 555TT, Hyola 571CL, and Hyola 61 hybrids do not cause changes in their grain yield.

\section{Acknowledgements}

The authors would like to thank the Embrapa/ Bayer project for supporting the research and the Coordination for the Improvement of Higher Education Personnel (CAPES) for the doctor scholarship granted to the first author.

\section{References}

Agostinetto, D., Fontana, L. C., Vargas, L., Markus, C., \& Oliveira, E. (2013). Habilidade competitiva relativa de milhã em convivência com arroz irrigado e soja. Pesquisa Agropecuária Brasileira, 48(10), 13151322. doi: 10.1590/S0100-204X2013001000002

Benincasa, M. M. P. (2003). Análise de crescimento de plantas: noções básicas. Jaboticabal: FUNEP.

Brandler, D. (2019). Interferência e nivel de dano econômico de plantas daninhas na cultura da canola. Dissertação de mestrado, Universidade Federal da Fronteira Sul, Erechim, RS, Brasil.

Carvalho, S. J. P., Moreira, M. S., Nicolai, M., LopezOvejero, R. F., Christoffoleti, P. J., \& Medeiros, D. (2005). Crescimento e desenvolvimento da planta daninha capim-camalote. Bragantia, 64(4), 591-600. doi: 10.1590/S0006-87052005000400009

Cechin, J., Vargas, L., Agostinetto, D., Zimmer, V., Pertile, M., \& Dal Magro, T. (2017). Fitness costs of susceptible and resistant radish biotypes to ALSinhibitor herbicides. Comunicata Scientiae, 8(2), 281-286. doi: 10.14295/cs.v8i2.1877

Companhia Nacional de Abastecimento (2018). Acompanhamento da safra brasileira de grãos safra 2017/18. Brasília: CONAB. Recuperado de http://www.conab.gov.br

Cruz, S. J. S. (2013). Características morfofisiológicas de plantas e produtividade de milho. Tese de doutorado, Faculdade de Ciências Agronômicas, Universidade Estadual Paulista, Botucatu, SP, Brasil.

Darmency, H. (2013). Pleiotropic effects of herbicideresistance genes on crop yield: a review. Pest Management Science, 69(8), 897-904. doi: 10.1002/ ps. 3522

Délye, C., Jasieniuk, M., \& Le Corre, V. (2013). Deciphering the evolution of herbicide resistance in weeds. Trends in Genetics, 29(11), 649-658. doi: 10.1016/j.tig.2013.06.001

Duke, S. O. (2015). Perspectives on transgenic, herbicideresistant crops in the United States almost 20 years after introduction. Pest Management Science, 71(5), 652-657. doi: 10.1002/ps.3863

Durigon, M. R., Mariani, F., Santos, F. M., Vargas, L., \& Chavarria, G. (2018). Properties of the enzyme acetolactate synthase in herbicide resistant canola. Bragantia, 77(3), 485-492. doi: 10.1590/1678-4499. 2017159 
Durigon, M. R., Vargas, L., Chavarria, G., \& Tomm, G. O. (2016). Indicações de uso e boas práticas de manejo da tecnologia Clearfield ${ }^{\circledR}$ em canola para as regiões Sul e Centro-Oeste. Revista Plantio Direto, $152(2), 22-30$.

Edwards, L., \& Hertel, K. (2011). Canola growth and development. Retrieved from http://www.dpi.nsw. gov. au/aboutus/

Frenkel, E., Matzrafi, M., Rubin, B., \& Peleg, Z. (2017). Effects of environmental conditions on the fitness penalty in herbicide resistant Brachypodium hybridum. Frontiers in Plant Science, 8(94), 1-10. doi: 10. 3389/fpls.2017.00094

Friesen, L. J. S., \& Powles, S. B. (2007). Physiological and molecular characterization of atrazine resistance in a wild radish (Raphanus raphanistrum) population. Weed Technology, 21(4), 910-914. doi: 10.1614/ WT-07-008.1

Krüger, C. A. M. B., Silva, J. A. G., Medeiros, S. L. P., Dalmago, G. A., Sartori, C. O., \& Schiavo, J. (2011). Arranjo de plantas na expressão dos componentes da produtividade de grãos de canola. Pesquisa Agropecuária Brasileira, 46(11), 1448-1453. doi: 10.1590/S0100-204X2011001100005

Londo, J. P., Bollman, M. A., Sagers, C. L., Lee, E. H., \& Watrud, L. S. (2011). Changes in fitness-associated traits due to the stacking of transgenic glyphosate resistance and insect resistance in Brassica napus L. Heredity, 107(4), 328-337. doi: 10.1038/hdy.2011.19

Majerowicz, N. (2013). Fotossíntese. In G. B. Kerbauy (Ed.), Fisiologia vegetal (2a ed., pp. 82-133). Rio de Janeiro: Guanabara Koogan.

Massinga, R. A., Al-Khatib, K., St. Amand, P., \& Miller, J. F. (2005). Relative fitness of imazamox-resistant common sunflower and prairie sunflower. Weed Science, 53(2), 166-174. doi: 10.1614/WS-03-152R1

McCourt, J. A., Pang, S. S., King-Scott, J., Guddat, L. W., \& Duggleby, R. G. (2006). Herbicide-binding sites revealed in the structure of plant acetohydroxyacid synthase. Proceedings of the National Academy of Sciences, 103(3), 569-573. doi: 10.1073/ pnas.0508701103

Ministério da Agricultura, Pecuária e Abastecimento (2018). Cultivarweb: gerenciamento de informação. Recuperado de http://sistemas.agricultura.gov.br/ snpc/cultivarweb/cultivares_registradas.php

Oliveira, L. M., Paiva, R., Alvarenga, A. A., \& Nogueira R. C. (2006). Análise do crescimento. In R. Paiva, \& L. M. Oliveira (Eds.), Fisiologia e produção vegetal (pp. 93-104). Lavras: UFLA.
Pozniak, C. J., Holm, F. A., \& Hucl, R. J. (2004). Field performance of imazamox resistant spring wheat. Canadian Journal of Plant Science, 84(4), 12051211. doi: 10.4141/P03-165

Purrington, C. B. (2000). Costs of resistance. Current Opinion in Plant Biology, 3(4), 305-308. doi: 10.1016/ s1369-5266(00)00085-6

Radosevich, S. R., Holt, J., \& Ghersa, C. (2007). Ecology of weeds and invasive plants: relationship to agriculture and natural resource management (3rd ed.). Hoboken: Wiley-Interscience.

Silva, A. C., Ferreira, L. R., Silva, A. A., \& Ferreira, F. A. (2005). Análise de crescimento de Brachiaria brizantha submetida a doses reduzidas de fluazifopp-butil. Planta Daninha, 23(1), 85-91. doi: 10.1590/ S0100-83582005000100011

Silva, L. C., Belterão, N. E. M., \& Amorim, M. S., Neto. (2000). Análise do crescimento de comunidades vegetais. (Circular Técnica, 34). Campina Grande: EMBRAPA-CNPA.

Systat Software Inc. (2008). Sigmaplot for Windows. Version 11. Retrieved from https://systatsoftware. com/ products/sigmaplot/

Taiz, L., \& Zeiger, E. (2017). Fisiologia vegetal (6a ed.). Porto Alegre: Artmed.

Tan, S., Evans, R. R., Dahmer, M. L., Singh, B. K., \& Shaner, D. L. (2005). Imidazolinone-tolerant crops: history, current status and future. Pest Management Science, 61(3), 246-257. doi: 10.1002/ps.993

Tardif, F. J., Rajcan, I., \& Costea, M. (2006). A mutation in the herbicide target site acetohydroxyacid synthase produces morphological and structural alterations and reduces fitness in Amaranthus powellii. New Phytologist, 169(2), 251-264. doi: 10.1111/j.14698137.2005.01596.x

Tomm, G. O., Ferreira, P. E. P., \& Vieira, V. M. (2014). Canola: híbridos avaliados em rede coordenada pela EMBRAPA. Passo Fundo: EMBRAPA Trigo. (1 Folder).

Tranel, P. J., \& Horvath, D. P. (2009). Molecular biology and genomics: new tools for weed science. BioScience, 59(3), 207-215. doi: 10.1525/ bio.2009.59.3.5

Tranel, P. J., \& Wright, T. R. (2002). Resistance of weeds to ALS-inhibiting herbicides: what have we learned? Weed Science, 50(6), 700-712. doi: 10.1614/0043-1745(2002)050[0700:RROWTA]2.0. $\mathrm{CO} ; 2$ 
Vargas, L., \& Roman, E. S. (2006). Resistência de plantas daninhas a herbicidas: conceitos, origem e evolução. (Documentos Online, 58). Passo Fundo: EMBRAPA Trigo. Recuperado de http://www.cnpt. embrapa. br/biblio/do/p_do58.htm

Vargas, L., Tomm, G. O., Ruchel, Q., \& Kaspary, T. E. (2011). Seletividade de herbicidas para a canola $P F B$-2. (Documentos Online, 130). Passo Fundo: EMBRAPA Trigo. Recuperado de http://www.cnpt. embrapa.br/biblio/do/p_do130.pdf

Vila-Aiub, M. M., Gundel, P. E., \& Preston, C. (2015). Experimental methods for estimation of plant fitness costs associated with herbicide-resistance genes. Weed Science, 63(Suppl. 1), 203-216. doi: 10.1614/ WS-D-14-00062.1

Vila-Aiub, M. M., Neve, P., \& Powles, S. B. (2009). Fitness costs associated with evolved herbicide resistance alleles in plants. New Phytologist, 184(4), 751-767. doi: 10.1111/j.1469-8137.2009.03055.x
Wei, D., Liping, C., Zhijun, M., Guangwei, W., \& Ruirui, Z. (2010). Review of non-chemical weed management for green agriculture. International Journal of Agricultural and Biological Engineering, 3(4), 5260. doi: 10.3965/j.issn.1934-6344.2010.04.052-060

Yu, Q., Han, H., Vila-Aiub, M. M., \& Powles, S. B. (2010). AHAS herbicide resistance endowing mutations: effect on AHAS functionality and plant growth. Journal of Experimental Botany, 61(14), 3925-3934. doi: 10.1093/jxb/erq205

Yu, Q., \& Powles, S. B. (2014). Resistance to AHAS inhibitor herbicides: current understanding. Pest Management Science, 70(9), 1340-1350. doi: $10.1002 /$ ps.3710 